A. Kapiton ${ }^{1}$, R. Baranenko², D. Tyshchenko ${ }^{3}$, O. Diachenko ${ }^{4}$

${ }^{1}$ National University «Yuri Kondratyuk Poltava Polytechnic», Poltava, Ukraine

${ }^{2}$ Uman National University of Horticulture, Uman, Ukraine

${ }^{3}$ Kyiv National University of Trade and Economics, Kiev, Ukraine

${ }^{4}$ Mariupol State University, Mariupol, Ukraine

\title{
PROSPECTS FOR THE CYBERSPACE DEVELOPMENT AND ITS SOCIO-PSYCHOLOGICAL CONSEQUENCES
}

\begin{abstract}
The article is devoted to the analysis of issues and research of the influence of social and psychological factors that influence the formation of Internet-dependent behavior of the individual in terms of increasing the role of cyberspace in today's conditions. The article examines the problems of interpersonal communication in the digital space, which leads to the virtualization of the living space of modern man, causing a certain specific danger, special needs and dependencies. The results of scientific research in this area are analyzed, namely those devoted to the impact of information technology on humans, based on the specifics of digitalization of educational space, in terms of modern development of the information environment of the world. The authors explored the main types of activities on the Internet: cognitive, game and communicative, which are directly responsible for specific personality changes.
\end{abstract}

Keywords: information technologies, cyberspace, Internet gaming disorders, virtualization, gaming.

\section{Introduction}

The purpose of this work is to identify the main problems of the Internet on modern society. The task of this work is to solve and eliminate as effectively as possible the pressure of information technology on humanity. In recent decades, new information technologies using personal computers and telecommunications have been developing rapidly. Information technology is a process that uses a set of tools and methods for collecting, processing and transmitting primary information to obtain information of new quality.

Analysis of recent research and publications. It is necessary to analyze the destructive processes occurring in the virtual socializing Internet environment, reflect the research data on the impact of virtual reality on the processes of socialization of youth, the factors of Internet dependence and proposals for its prevention. According to O. Evzikova, information is not matter and not energy, but something else. E. Borodina, O. Shefer, S. Alyoshin introduces the concept of information as a dynamic image of the world around us, which is formed in the flow of sensations integrated by a living being. The process of accumulation of information was formed during the long history of civilization, while improving the methods of its transmission - from rock drawings to the emergence of alphabetic writing [1, 2, 5, 6].

In today's world, we see that the most powerful source of information is the Internet and the so-called cyberspace created by it. The Internet in its development has passed the way from the professional sphere of communication of programmers to the sphere of free communication, realizes wider in comparison with professional personal interests. The Internet today is not just a network of interconnected computers, but a community of people who use the Internet. In this regard, the scientific literature claims the term "psychology of the Internet." Research in this area, namely on the impact of information technology on humans, mainly psychological aspects, is conducted by scientists from around the world.

\section{Main part}

When the development of the Internet was just beginning, everyone was interested in the fact that the useful can be extracted from the ability to communicate using a computer. However, it is time to look at what is happening as a social process, as each individual through the Internet can convey their thoughts to a huge number of people who together are trying to transform reality. The WWW, as the Internet is called, has already connected millions of users with invisible electronic threads. Today we do not know how the individual and social behavior of a person will be affected by communication, in which millions of people are involved, but we can say with confidence that the impact will be, and will be noticeable. For example, by participating in the life of cyberspace, social minorities find strength and influence, various movements are organized, and third world countries make huge information leaps forward. Therefore, all over the world now attach great importance to those projects that involve the organization of access of the general population to the Internet.

There are three main types of activities on the Internet which correspond to personality changes: cognitive; gaming; communicative $[1,3,6]$. In this sense, the possibilities of the Internet are not limited, so it is rightly called a springboard into the future. Indeed, on the one hand, today it is the world's richest treasury of knowledge, which is the property of all mankind, but on the other - the Internet has accumulated a huge amount of negative information that also affects people. It is necessary to analyze the destructive processes occurring in the virtual socializing Internet environment, reflect the research data on the impact of virtual reality on the processes of socialization of youth, the factors of Internet dependence, proposals for its prevention.

Modern man today is no longer a classic Homo Sapiens, but a much virtualized bio-socio-electronic subject, which directs its activity not only in the social, spiritual sphere, the environment and the world of culture, but also in a new virtual environment that forms its 
new opportunities and needs. The living space of the individual, a significant place in which is work, communication, education, creativity, leisure, is supplemented by new opportunities and forms. Due to virtualization, it first doubles when a person combines active life in two dimensions (digital and real), and then there is a gradual shift towards a virtual lifestyle (which requires less effort and is controlled by the individual). Significant changes associated with the introduction of information technology in the surrounding modern world, in its communication, education, work, leisure and lead to the fact that in the field of values there are new guidelines: information, mobility, accessibility, speed of interaction, etc. In search of sources of communication, creativity, knowledge, self-expression, people are increasingly turning not to the real but to the virtual sphere, which already dominates his consciousness and life in a number of parameters.

Thus, the development of the Internet and the field of high technology pose many problems, one of which, in my opinion, is the problem of loneliness and alienation. Internet gambling addiction is currently classified as a mental disorder only in the context of gaming (as a gambling addiction), Internet addiction as a mental disorder is qualified by most researchers, although it raises significant concerns. Potential addicts belonging to the risk group are usually people prone to other types of addiction, prone to depression, phobias, as well as difficulties in the social sphere, in the implementation of self-development. The transition of involvement in the form of addiction is enhanced in the presence of existential, sociocultural and psychological factors. At the same time, the formation of Internet gambling addiction is a consequence of the development of consumer society, advertising of gaming and media products, imposed by producers of information products and resource needs. Traditionally, there are "alienation as a universal characteristic of human existence, as a characteristic of the psychological state of man, and finally as a characteristic of a certain social state, when a person's creative activity is limited and he is enslaved by the product of his own activity. Different grounds for alienation cause different forms of its manifestation, so in this sense, alienation is multifaceted.

This suggests that the solution to this problem lies in different areas - both legal, regulatory activities of sellers of Internet services and gaming products, and social, cultural, interpersonal. The phenomenon of alienation has existed at all times, it is not an absolute affiliation of past years [3].

First of all, this problem came into the field of view of physicians and psychologists, because the consequences of the superiority of virtual communication and computer games in some c assess led to devastating effects on the individual. Thus, among medical professionals, the approach has been established that a person, spending all his free time playing computer games, feels pleasure similar to drugs. We considers, Internet addiction a new danger for a person, like a drug, the manifestation of which is expressed both in increased arousal and in the deepening of subsequent depressive states of the user. A new type of dependence is manifested in the desire for constant presence in the virtual world (playful or communicative), neglect of real social ties, weakening of cognitive, creative activity, increasing passive. Social factors in the formation of addictions are also essential: it is the desire to communicate with others, socialization, which in a high-tech society moves into the information space. If a modern young person does not accept these conditions, it inevitably finds itself in isolation, as most young people belong to the Internet generation, play video games, communicate on social networks. Virtual communication due to distance allows a person to be simultaneously in several places (physically he is present in one place, mentally - spends time in another), being in unfavorable social conditions, feeling his need for others, difficulties in real communication, a person looking for interaction with virtual friends and partners, formed in the modern generation in a new social need. Most gamers and addicts have problems with real communication, although this is not a general rule (Fig. 1) [1].

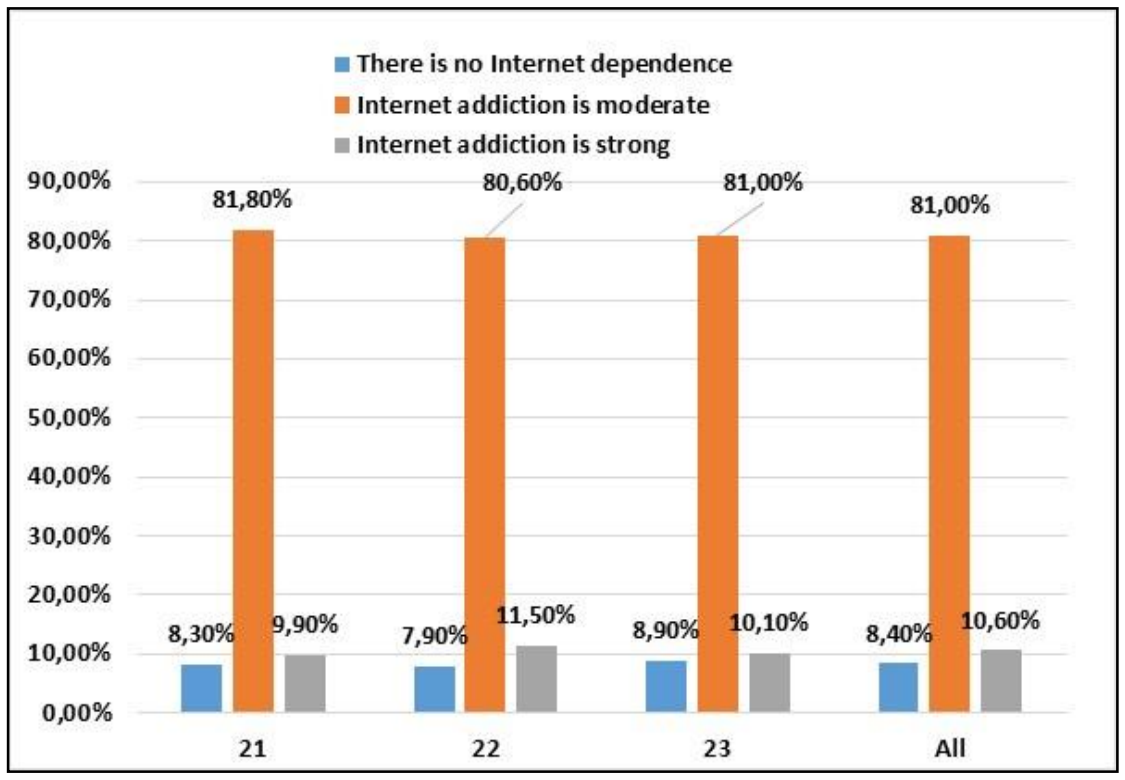

Fig. 1. Internet dependence rate (by age, $\%$ ) 
In modern conditions, hyperactive and overly communicative people find realization for themselves also in virtual interaction, gathering a large number of "friends", "followers", readers of their blogs, messages in networks. However, the movement of attention, interests, circles of acquaintances and friends in virtual communities gradually weakens real social ties, its social circle is reduced, it becomes more closed and prefers real meetings with people - Internet sessions or games. Types of modern Internet addiction are becoming more diverse, they are accompanied by online shopping, viewing a variety of videos and photos, which take up more and more time, displacing book reading, selfeducation, creativity, real communication. However, these processes are not spontaneous, inherent in the individual; on the contrary, they are formed purposefully, as imposed on human needs by various advertising firms, agencies for the production and sale of video products. Games and media products are a profitable commodity in the modern market, and their promotion is aimed at the formation of modern man's interest, satisfaction, and then the need for them. In this case, we are dealing with the economic aspect of the problem of forming an Internet gambling addiction. Society is subject to the paradigm of selling various services and goods that are redundant for man, and in order to convince him of the need to purchase them, you need information "tricks": advertising "cookies", banners, etc., which are crowded with social networks, games portals, mail, educational and other sites. The video game business (including game consoles and gadgets) focuses its efforts on creating an imposed need for games, which for people from the above risk groups can turn into addictions that require treatment.

However, it is important for society to realize this problem as a threat to the individual (because in most countries still prevails neglect of this problem) and the creation of a legal framework governing the use of advertising in the information space, its gradual regulation to protect people from manipulative influence not only with physical threats, but also with threats to culture, freedom, intelligence, etc.

\section{Conclusions}

Thus, the problems of virtualization of human living space, the formation of the information society, a powerful sector of services and entertainment are becoming objective factors in the development of new addictions and lack of freedom of modern man. The most significant subjective factors are related to psychological, existential, personal characteristics, the objective factors include social, cultural and economic. This means that the solution to emerging problems can not lie only in the field of medicine and psychology and even in the field of education. It is unlikely to be able to resist the efforts of the business community of the information world, or it will be local and private. That is why it is advisable to carefully study this problem in order to further analyze it and improve ways to eliminate its negative impact on the development of personality in terms of increasing digitalization of all areas of today.

\section{REFERENCES}

1. Інтернет-залежність української молоді: сучасний стан проблеми URL: https://commons.com.ua/uk/internet-zalezhnist/

2. Evzikova, O. Google Education Tools URL: http://teachtech.ru/instrumenty-veb-2-0/instrumenty-google-dlyaobrazovaniya.html.

3. Hafiiak, A. (2019). Problems of professional competence of future specialists on information and communication technologies in universities. Series: Education And Pedagogy, 10 (2), 15-18.

4. Інтернет-залежність: як діагностувати та позбутися? URL: https://thepoint.rabota.ua/internet-zalezhnist-yakdiahnostuvaty-ta-pozbutysya/

5. Mozhaev, O., Kuchuk, H., Kuchuk, N., Mykhailo, M., Lohvynenko, M. (2017), "Multiservice network security metric", 2nd International Conference on Advanced Information and Communication Technologies, AICT 2017 - Proceedings, pp. 133136, DOI: https://doi.org/10.1109/AIACT.2017.8020083

6. Hafiiak, A., Borodina, E., Shefer, O., Alyoshin, S. (2019). The information technology and mobile applications appliance for the future specialists preparation in higher education institutions. Control, Navigation and Communication Systems, 3 (55), 76-79.

\section{Перспективи розвитку кіберпростору та його соціально-психологічні наслідки}

А. Капітон, Р. Бараненко, Д. Тищенко, О. Дяченко

Анотація. Стаття присвячена аналізу проблематики та дослідженню впливу соціальних і психологічних факторів, які впливають на формування Інтернет-залежної поведінки особистості в умовах підвищення значення ролі кіберпростору в умовах сьогодення. В статті досліджено проблеми міжособистісної комунікації в цифровому просторі, що призводить до віртуалізації життєвого простору сучасної людини, викликаючи певну специфічну небезпеку, особливі потреби і залежності. Проаналізовано результати наукових досліджень в цій області, а саме ті, що присвячено темі впливу інформаційних технологій на людину, спираючись на специфіку цифровізації освітнього простору, з точки зору сучасного розвитку інформаційного середовища світу. Авторами досліджено основні різновиди діяльності в інтернет: пізнавальна, ігрова та комунікативна, які безпосередньо відповідають за конкретні зміни особистості.

Кл ючов і сл ов а: інформаційні технології, кіберпростір, Інтернет-ігрові розлади, віртуалізація, геймерство. 